\title{
BACTERIAL INFESTATION IN DIFFERENT FISH AT RAJSHAHI
}

\author{
H Khatun, M D Hossain*, S N Jahan and D A Khanom
}

\begin{abstract}
The present study was carried out from July 2005 to June 2007 and diseased freshwater fishes were collected from different water bodies and fish landing centre of three study areas, namely City Corporation area, Rajshahi; Paba upazila and Charghat upazila, Rajshahi. In the present study the load of bacteria in lesion, liver and kidney of $H$. molitrix showed considerable variation in different months during the study period. Monthly variation of bacterial load in body lesion varied from $3.17 \times 10^{4}$ CFU/g (July’05) to $2.13 \times 10^{7} \mathrm{CFU/g}$ (March’07), in liver it varied from $7.17 \times 10^{3} \mathrm{CFU} / \mathrm{g}$ (July’05) to $5.13 \times 10^{6} \mathrm{CFU} / \mathrm{g}$ (March’06) and in kidney it varied from $5.87 \times 10^{3} \mathrm{CFU} / \mathrm{g}$ (July’05) to $6.33 \times 10^{5}$ CFU/g (March'06). From two years observation, monthly variation of bacterial load in 3 sampling ponds were varied from $4.00 \times 10^{6} \mathrm{CFU} / \mathrm{ml}$ (June’07) to 3.93 $\times 10^{7} \mathrm{CFU} / \mathrm{ml}$ (July’05) in case of pond-1. In pond-2 bacterial load varied from $1.27 \times 10^{6} \mathrm{CFU} / \mathrm{ml}$ (May’07) to $5.33 \times 10^{7} \mathrm{CFU} / \mathrm{ml}$ (September'06). In pond-3 the bacterial load varied from $2.10 \times 10^{6} \mathrm{CFU} / \mathrm{ml}$ (June'07) to $2.10 \times 10^{8} \mathrm{CFU} / \mathrm{ml}$ (July’06).
\end{abstract}

Keywords: Disease, Bacterial infestation, Bacterial load

\section{INTRODUCTION}

Bacteria are one of an important causative agent of fish diseases in both wild and cultured fish and are responsible for serious economic losses. Few pathogens infect both freshwater and marine fish. Many pathogens can present as only skin infections especially flexibacteria, aeromonads and vibrios. Fishes were present with ulcer, hemorrhage, scale loss, tail and fin rot, dropsy includes several bacterial diseases (Chowdhury, 1997). The bacteria of the genera Aeromonas, Pseudomonas are ubiquitous facultative parasites, where potential pathogenicity becomes threatening for fish, only under unfavourable conditions. They belong to the normal bacterial flora of aquaria, the water of hatcheries, fish farms and bodies of water for domestic use, in which the appearance of the colonization of these bacteria in the skin fins, gills and intestinal lumen of fish. Most fish pathogenic bacteria can reside in the environment or on/in apparently normal fish. Thus, infections are often precipitated by some stress that upsets the natural defenses against the agents (e.g. overcrowding, low DO, high ammonia).

A. hydrophila is the most common cause of bacterial haemorrhagic septicaemia. The disease occurs in three distinct form, (a) abdominal dropsy, characterized by distension of the visceral cavity with fluid, (b) ulcerative, characterized by skin and muscle lesion, and (c) generalized bacterial hemorrhagic septicaemia. It has also been given several other names, e. g. infections, dropsy, red disease. The

* Corresponding author: Associate Professor, Department of Fisheries, University of Rajshahi, Rajshahi-6205, Bangladesh 
disease is worldwide affecting cultured cyprinids and other pond fish. It is commonly associated with fish populations suffering from stress. Fish are abnormally dark, show large subcutaneous haemorrhages and have distended abdomen. A. hydrophila caused a severe disease outbreak. Cultured fish suffer from Aeromonas sp. and Pseudomonas sp. infections with similar signs like dermal lesion, scale loss, frayed fins, tail and fin rot and Dropsy. Red skin disease is caused by Pseudomonas fluorescens in China. Red spot disease was caused by Aeromonas sp.

In Bangladesh, there is no proper scientific research on bacterial disease in fish. Study of aquatic bacteria associated with fish is very limited in Bangladesh. Few attempts have been taken in order to assess the bacterial population in aquatic environment and their involvement in causing diseases in fish. Chowdhury et al. (1997) reported Aeromonas sp. and Pseudomonas sp. are very common in fish disease specially in carp and live fishes for these a successful investigation need to know, what kind of bacteria present associated with diseased fish, the quantity of bacteria present in different organs of diseased fish and pond water are harmful or not for fish culture.

The aim of the present study is to identify the common bacterial diseases in freshwater fishes. The loads in different organs and in the sampling ponds are to be assessed.

\section{MATERIALS AND METHODS}

Procedure: Petridishes, test tube, glass pipettes, conical flask, tips, cotton physiological saline, Agar media were sterilized in an autoclave at $121^{\circ} \mathrm{C}$ for 20 minutes. Nutrient Agar media was made by $8.4 \mathrm{~g}$ agar and distilled water up to $300 \mathrm{ml}$ and TSA media was made by $19 \mathrm{~g}$ agar and distilled water up to $500 \mathrm{ml}$. The conical flask was shaken with stopper for dilution of Agar and distilled water. Conical flasks containing agar were kept in an autoclave at $121^{\circ} \mathrm{C}$ for 20 minutes. Then the sterilized agar

solution was poured separately $(20 \mathrm{ml})$ in the petridishes from conical flask. Petridishes were closed and kept at room temperature for one hour.

\section{Collection of diseased fish}

18 types of fishes were collected from different fish landing centre, different water body and sampling ponds from July 2005 to June 2007. Bacterial isolates were collected from ulcer type lesion on body surface such as caudal, dorsal, ventral, lateral, head lesion and fin rot of different fish species viz. $C$. catla, L. rohita, C. mrigala, H. molitrix, C. idellus, C. carpio var. specularis, C. carpio var. communis, P. gonionotus, L. calbasu, P. ticto, C. punctatus, C. striatus, C. batrachus, H. fossilis, M. tengara, M. armatus, $M$. pancalus, $A$. testudineus. The samples were brought to the laboratory immediately after collection for bacteriological study.

\section{Bacteriological investigation}

Tryptic Soy Agar (TSA) was used for culture of Aeromonas sp. Nutrient Agar was used for culture of Pseudomonas sp. And finally the identification of Aeromonas sp. and Pseudomonas sp. was made by Cowan and Steel's Manual, for the identification of Medical Bacteria edited by Barrow and Felthem (1993) and confirmed with the help of Bergey’s Manual (Krieg and Holt, 1984). 


\section{Determination of bacterial load in fish and pond water}

Bacterial load in diseased $H$. molitrix

Sampling: Three specimens of $H$. molitrix were collected monthly from the sampling pond. Experiment was carried out by the method of Banu et al. (2001). Samples were collected from body lesion, liver and kidney of fish.

Body lesion: Liver samples were collected monthly for investigation. Fishes were killed by a light hurt on the neck region and then the lesion was collected by sterile scalpel and kept in a pre-weighed sterile weighing boat. After weighed (0.1g) the lesion was homogenized for the preparation of suspension in sterile $1 \mathrm{ml}$ physiological saline $(0.85 \% \mathrm{NaCl})$. These samples were diluted in sterile $9 \mathrm{ml}$ physiological saline through 10 fold dilution. Pteridishes were set out, 3 plates for dilution were tested and each dilution was micropipetted $(100 \mu \mathrm{l})$ into the centre of the petridishes using sterile tips for each dilution. With a sterilized glass rod the content was spread as quickly as possible. Each dilution had mixed with the help of cyclomixture before spread in petridish. Then the petridishes were inverted and kept in incubator at $25^{\circ} \mathrm{C}$ for $24-48$ hours. Colony was counted by directed counting method and then the number of bacteria was calculated.

Liver: The body surface of fish samples were disinfected with $70 \%$ ethyl alcohol. The abdomen of diseased fish was opened by aseptic dissection and then the liver was taken out carefully with the help of sterilized forceps. The liver samples after being weighed $(0.1 \mathrm{~g})$ individually in a sterile weighing boat was homogenized for preparation of the suspension in physiological saline. Thereafter, the suspension was diluted in physiological saline through 10 fold dilution for incubation on the culture media.

Kidney: The kidney samples were prepared following the same procedure as done for the preparation of liver. Nutrient Agar was used for culture.

Bacterial load in pond water: Water samples were collected from 3 sampling ponds, once a month during the study period. Water samples were collected in sterilized reagent bottles from the depth of 25-35 cm below the surface at the time from 10:00 am to 12:00 pm. These samples were $1 \mathrm{ml}$ diluted in sterile $9 \mathrm{ml}$ physiological saline through 10 fold dilution for inoculation on the culture media (Nutrient Agar).

\section{RESULTS AND DISCUSSION}

\section{Identification of bacteria}

The investigations demonstrated that freshwater fishes were affected by infection with different types of bacteria. During the investigated period July 2005 - June 2007 dermal lesion, ulcer, EUS, tail and fin rot, scale loss type of bacterial diseases were very common. Bacterial investigation were collected from ulcer type of lesion and tail and fin rot type of diseases. The recovered bacterial genera were identified as Aeromonas sp. and Pseudomonas sp (Table-1). Aeromonas sp. are gram negative, acid 
fast, non sporing rod with a single polar flagellum, measuring about 1.0-1.5 $\times 6.5 \mu \mathrm{m}$. Bacteria of the Pseudomonas sp. are gram negative, non acid fast, non sporing rod with a single polar flagellum, measuring about $2 \times 6.4 \mu \mathrm{m}$.

Table 1: Name of fish investigated and positive isolation of Aeromonas sp. and Pseudomonas sp.

\begin{tabular}{|l|l|l|l|l|}
\hline $\begin{array}{l}\text { Sl. } \\
\text { No. }\end{array}$ & Species & Site of isolation & $\begin{array}{l}\text { Aeromonas sp. } \\
\text { positive isolation }\end{array}$ & $\begin{array}{l}\text { Pseudomonas sp. } \\
\text { positive isolation }\end{array}$ \\
\hline 1 & C. catla & Lesion, Fin & + & + \\
\hline 2 & L. rohita & Lesion, Fin & + & + \\
\hline 3 & C. mrigala & Lesion, Fin & + & + \\
\hline 4 & H. molitrix & Lesion, Fin & + & + \\
\hline 5 & C. idellus & Lesion & + & + \\
\hline 6 & C. carpio var communis & Lesion & - & + \\
\hline 7 & C. carpio var specularis & Lesion & - & + \\
\hline 8 & P. gonionotus & Lesion & + & + \\
\hline 9 & L. calbasu & Lesion & + & + \\
\hline 10 & P. ticto & Lesion, Fin & - & + \\
\hline 11 & C. punctatus & Lesion, Fin & + & + \\
\hline 12 & C. striatus & Lesion, Fin & + & + \\
\hline 13 & C. batrachus & Lesion, Fin & + & + \\
\hline 14 & H. fossilis & Lesion & + & + \\
\hline 15 & M. tengara & Lesion & - & + \\
\hline 16 & M. armatus & Lesion & + & + \\
\hline 17 & M. pancalus & Lesion & + & + \\
\hline 18 & A. testudineus & Lesion, Fin & + & + \\
\hline & & & \\
\hline
\end{tabular}

$+=$ present, $-=$ not present

Circular, smooth raised colonies were produce on both Agar (TSA and nutrient agar). Colonies of Aeromonas sp. were yellowish and Pseudomonas sp. creamy whitish. Glucose fermentation is a critical reaction that differentiates the Aeromonas sp. from Pseudomonas sp. Bacteria were inoculated into two tubes of oxidation fermentation (OF) basal medium supplemented with $1 \%$ glucose. The medium in one tube is overlaid with a plug of sterile petrolatum and both tubes are incubated at $25^{\circ} \mathrm{C}$ for 24 to 48 h. Results were interpreted as follows: yellow coloration in both tubes indicates acidic fermentation of glucose typical of Aeromonas sp., whereas yellow coloration only in the tube without petrolatum indicates oxidation of glucose characteristic of Pseudomonas sp. Production of gas is evidenced in either test by the formation of bubbles in the medium. Although most strains of Aeromonas sp. produce gas during the fermentation of glucose. Bacterial strains were identified by conventional biochemical test (Table 2). 
Table 2: Identifying characteristics of fish pathogenic strain Aeromonas sp. and Pseudomonas sp.

\begin{tabular}{|l|c|c|}
\hline \multicolumn{1}{|c|}{ Identifying character } & Aeromonas sp. & Pseudomonas sp. \\
\hline Colony & Yellowish & Creamy whitish \\
\hline Morphology & Small rods & Small rods \\
\hline Gram stain & - & - \\
\hline Catalase & + & + \\
\hline Oxidase & + & + \\
\hline Gelatin liquefaction & + & - \\
\hline Indole production & F & O \\
\hline OF test & + & - \\
\hline Arabinose & + & - \\
\hline Manitol & + & - \\
\hline Sucrose & + & - \\
\hline Inositol & + & - \\
\hline Esculin hydrolysis & + & - \\
\hline Voges-Proskauer reaction & - & + \\
\hline Ammonium production (nutrient growth) & G & S \\
\hline Glucose & & + \\
\hline
\end{tabular}

Note:

$$
\begin{aligned}
& +=\text { positive reaction, }-=\text { negative reaction } \\
& \mathrm{F}=\text { fermentation, } \mathrm{O}=\text { oxidation, } \mathrm{G}=\text { gas, } \mathrm{S}=\text { acid }
\end{aligned}
$$

The present findings support the previous works done by Sarker et al. (1999). Chowdhury (1998) reported the involvement of Aeromonas sp. and Pseudomonas sp. in the ulcer type diseases in freshwater fishes. Only Aeromonas sp. and Pseudomonas sp. were isolated from EUS affected freshwater fishes in the endemic area of Punjab, Pakistan (Rab et al., 2001). These results agree with present study and Aeromonas sp. and Pseudomonas sp. were isolated from diseased fish. Only Pseudomonas sp. were identified from C. carpio var. communis, C. carpio var. specularis, $M$. tengara and P. ticto and Aeromonas sp. and Pseudomonas sp. both were identified from all the rest. In India a broad spectrum of bacterial forms belonging to Pseudomonas sp. Bacillus sp., Anthrobacter sp. Staphylococcus sp., Micrococcus sp., Actinomycete sp. and Aeromonas hydrophila were isolated from disease fish C. mrigala, L. rohita and C. catla (Kumar and Day, 1992). A. hydrophila, A. veronii biover sobria, A. veronii biover veronii, A. schubertii and A. jandaei were isolated from EUS affected fishes in Bangladesh (Khan, 2001). Aeromonas, Pseudomonas, Flavobacterium, Micrococcus and Staphylococcus were isolated from ulcer type of disease in wild fishes of Bangladesh (Majumder et al., 2001). Aeromonas and Pseudomonas bacteria were isolated from infected fin and viscera of Asian catfish, Clarias batrachus (Saha et al., 1998). 


\section{Load of bacteria in lesion, liver and kidney of $H$. molitrix}

Bacterial load in body lesion, liver and kidney of fish sample during the study period July 2005 - June 2006 were found to considerable variation. The bacterial load in body lesion varied from $3.17 \times 10^{4}$ CFU/g (July 2005) to $2.13 \times 10^{7} \mathrm{CFU} / g$ (March 2006), in liver varied from $7.17 \times 10^{3} \mathrm{CFU} / \mathrm{g}$ (July 2005) to $5.13 \times 10^{6} \mathrm{CFU} / \mathrm{g}$ (March 2006) and in kidney varied from $5.87 \times 10^{3} \mathrm{CFU} / \mathrm{g}$ (July 2005) to $6.33 \times 10^{5}$ CFU/g (March 2006), respectively The lowest and the highest bacterial load in all the three organs were found in the month of July 2005 and March 2006. There were no diseased fish found in the month of May and June 2006.

In the second year (July 2006-June 2007) minimum and maximum length varied from $24.2 \mathrm{~cm}$ (September 2006) to $36.6 \mathrm{~cm}$ (March 2007) and weight varied from 176.00g (September 2006) to $345.00 \mathrm{~g}$ (April 2007). The bacterial load in body lesion varied from $1.27 \times 10^{6} \mathrm{CFU} / \mathrm{g}$ (September 2006) to $2.23 \times 10^{7} \mathrm{CFU} / \mathrm{g}$ (March 2007), in liver varied from $1.10 \times 10^{5} \mathrm{CFU} / \mathrm{g}$ (December 2006) to $3.03 \times 10^{6} \mathrm{CFU} / \mathrm{g}$ (March 2007) and in kidney varied from $6.17 \times 10^{3} \mathrm{CFU} / \mathrm{g}$ (January 2007) to $5.67 \times 10^{5}$ CFU/g (March 2007), respectively (Appendix Table 4.1). The highest bacterial load in all the three organs were found in the month of March 2007. There were no diseased fish found in the month of July, August 2006 and May, June 2007.

From two years observation, monthly variation of bacterial load in body lesion varied from $3.17 \times 10^{4}$ CFU/g (July'05) to $2.13 \times 10^{7} \mathrm{CFU/g}$ (March'07), in liver it varied from $7.17 \times 10^{3} \mathrm{CFU} / \mathrm{g}$ (July'05) to $5.13 \times 10^{6} \mathrm{CFU} / \mathrm{g}$ (March'06) and in kidney it varied from $5.87 \times 10^{3} \mathrm{CFU} / \mathrm{g}$ (July'05) to $6.33 \times 10^{5}$ CFU/g (March’06).

\section{Bacterial load in pond water}

In the First year bacterial load of sampling pond-1 was varied from $4.37 \times 10^{6} \mathrm{CFU} / \mathrm{ml}$ (June 2006) to $3.93 \times 10^{7} \mathrm{CFU} / \mathrm{ml}$ (July 2005). Bacterial load of pond water varied from $4.00 \times 10^{6} \mathrm{CFU} / \mathrm{ml}$ (June 2007) to $3.73 \times 10^{7} \mathrm{CFU} / \mathrm{ml}$ (September 2006) for the second year observation.

In the sampling pond-2 the minimum and maximum bacterial load $1.33 \times 10^{6} \mathrm{CFU} / \mathrm{ml}$ (June 2006) to $5.33 \times 10^{7} \mathrm{CFU} / \mathrm{ml}$ (September 2005) were observed in the first year. In the second year minimum and maximum bacterial load $1.27 \times 10^{6} \mathrm{CFU} / \mathrm{ml}$ (May 2007) to $5.43 \times 10^{7} \mathrm{CFU} / \mathrm{ml}$ (September 2006) was found.

In case of sampling pond-3 the minimum and maximum bacterial load $3.23 \times 10^{6} \mathrm{CFU} / \mathrm{ml}$ (May 2006) to $2.10 \times 10^{8} \mathrm{CFU} / \mathrm{ml}$ (July 2005) were observed in the first year. In the second year minimum and maximum bacterial load $2.10 \times 10^{6} \mathrm{CFU} / \mathrm{ml}$ (June 2007) to $2.13 \times 10^{8} \mathrm{CFU} / \mathrm{ml}$ (July 2006) were observed.

The highest bacterial loads in all three organs were found in the month of March. Horseley (1973) investigated relationship between the bacterial flora of Salmon and its environment. He recorded $10^{2}$ to $10^{3}$ bacteria per $\mathrm{cm}^{2}$ at skin and similar number of bacteria found/ $\mathrm{ml}$ of water. Charganowski (1985) reported that the total bacterial population was $1.1 \times 10^{3}$ cells $/ \mathrm{m}^{3}$ of water in lake Arlington and 
cell volume was substantially larger in winter than summer and were negatively correlated with the temperature. Iqbal (1995) reported that the total bacterial loads in pond water, body slime and kidney of fish at Trisal Fish Seed Multiplication Farm, varied from $1.3 \times 10^{2}$ to $5.9 \times 10^{5} \mathrm{CFU} / \mathrm{ml}, 5.4 \times 10^{3}$ to $8.5 \times 10^{7} \mathrm{CFU} / \mathrm{g}$ and 0.0 to $2.4 \times 10^{4} \mathrm{CFU} / \mathrm{g}$, respectively, while those of the Jhalak Fish Farm were $2.0 \times 10^{2}$ to $3.0 \times 10^{5} \mathrm{CFU} / \mathrm{ml}, 3.8 \times 10^{2}$ to $2.3 \times 10^{8} \mathrm{CFU} / \mathrm{g}$ and 0.0 to $5.3 \times 10^{4} \mathrm{CFU} / \mathrm{g}$. Banu et al. (2001a) reported that the total bacterial load in pond water varied from $1.39 \times 10^{5}$ to $3.11 \times 10^{7} \mathrm{CFU} / \mathrm{ml}$ in surface water and $5.90 \times 10^{7} \mathrm{CFU} / \mathrm{ml}$ in bottom water. They also reported that the total bacterial loads in body slime, liver and kidney of C. mrigala varied from $0.58 \times 10^{3}$ to $2.37 \times 10^{7} \mathrm{CFU} / \mathrm{g}, 0.22 \times 10^{3}$ to $9.64 \times 10^{6} \mathrm{CFU} / \mathrm{g}$ and $0.15 \times 10^{3}$ to $9.36 \times 10^{6} \mathrm{CFU} / \mathrm{g}$, respectively. These results agree with the findings of the present study.

The present study revealed that the bacterial load in body lesion in $H$. molitrix varied from $3.17 \times 10^{4}$ CFU/g (July 2005) to $2.23 \times 10^{7} \mathrm{CFU} / g$ (March 2007), in liver varied from $7.17 \times 10^{3} \mathrm{CFU} / \mathrm{g}$ (July 2005) to $5.13 \times 10^{6} \mathrm{CFU} / \mathrm{g}$ (March 2006) and in kidney varied from $5.87 \times 10^{3} \mathrm{CFU/g}$ (July 2005) to $6.3 \times 10^{5}$ CFU/g (March 2006).

In the present study the highest bacterial load in three sampling pond water was in the month of July 2006 and lowest was in the month of May, 2007. Bacterial load varied from $4.00 \times 10^{6} \mathrm{CFU} / \mathrm{ml}$ (June 2007) to $3.93 \times 10^{7} \mathrm{CFU} / \mathrm{ml}$ (July 2005) in sampling pond-1. In the sampling pond-2, bacterial load varied from $1.27 \times 10^{6} \mathrm{CFU} / \mathrm{ml}$ (May 2007) to $5.43 \times 10^{7}$ (September 2006). In the sampling pond-3 it was observed that bacterial load was varied from $2.10 \times 10^{6} \mathrm{CFU} / \mathrm{ml}$ (June 2007) to $2.13 \times 10^{8} \mathrm{CFU} / \mathrm{ml}$ (July 2006).

\section{REFERENCES}

Banu, A. N. H., M. A. Islam and M. B. R. Chowdhury, 2001. Bacterial load in pond water and different organs of a Indian major carp Cirrhinus mrigala Ham. Bangladesh J. Fish. Res., 5(1): 53-58.

Barrow, G. I. and R. K. M. Feltham, 1993. Cowan and Stell's Manual for the Identification of Medical Bacteria. 3rd edn. Cambridge University Press. 311pp.

Charganowski, T. H., 1985. Seasonal abundance and biomass of bacteria in a South Western reservoir. USA. Hydrobiol., 127(2): 117-123.

Chowdhury, M. B. R. and M. A. Baqui, 1997. Bacterial flora in farmed carp (Labeo rohita) in Bangladesh. In: Disease in Asian Aquaculture III (eds. T. Flegel and I. H. MacRae), Fish Health Section, Asian Fisheries Society, Manila. pp. 101-105.

Chowdhury, M. B. R., 1998. Involvement of aeroimonads and pseudomonads diseases of farmed fish in Bangladesh. Proceedings of the International Symposium on Diseases in Marine Aquaculture, Hiroshima, 3-6 October 1997. Gyobyo-Kenkyu, Fish Pathology, 33: 4, 247-254.

Horseley, R. W., 1973. The bacterial flora of the Atlantic Salmon (Salmo salar L.) in relation to its environment. J. Appl. Bacteriology, 36: 377-386.

Iqbal, M. M., 1995. Bacteriological studies on farmed mrigal, Cirrhinus mrigala. M. Sc. Thesis. Department of Fisheries Biology and Limnology, BAU, Mymensingh. 161pp.

Khan, M. H., 2001. Epidemiological studies on epizootic ulcerative syndrome (EUS) in Bangladesh. Ph.D. thesis, Institute of Aquaculture, University of Stirling, Scotland, UK. 182pp. 
Kreig, N. R. and J. G. Holt, 1984. Bergey's Manual of Systematic Bacteriology. Volume-1. Williams and Wilkins. 964pp.

Kumar, D. and R. K. Day, 1992. Outbreak of epizootic ulcerative syndrome of fishes in India. A preliminary report. In: Aquaculture Research needs for 2000 AD. Oxford and IBH publishing co. New Delhi India. pp. 233-242.

Majumder, B., M. G. A. Sarker, M. H. Khan and M. B. R. Chowdhury, 2001. Incidence of ulcer type of disease in wild fishes of Bangladesh. Bangladesh J. Fish. Res., 5(2): 163-168.

Rab, A., M. Afzal, N. Akhtar, A. Barlas and M. Qayyum, 2001. Incidence of epizootic ulcerative syndrome (EUS) in freshwater fishes in the endemic area of Punjab, Pakistan. Bangladesh J. Fish. Res., 5(1): 4552.

Saha, J. K., M. Z. Huq, A. N. H. Banu and K. J. Chandra, 1998. The effect of various chemicals in the treatment of tail and fin rot of Asian Catfish, Clarias batrachus (Linn.). The Bangladesh Veterinarian, 15(1-2): 37-41.

Sarker, M. G. A., A. Sarker and M. B. R. Chowdhury, 1999. Occurrence of aeromonad pathogens in carp fingerling at Mymensingh region of Bangladesh. Bangladesh J. Fish., 22: 7-12. 